\title{
Effect of Repeated Herbicide Applications on Green Sagewort in North Central Nebraska
}

\section{A. MORROW AND M. K. MCCARTY}

Highlight: Plots were established in 1971 to determine the effect of herbicides on stands of green sagewort (Artemisia campestris L.). Treatments were applied in 1971, 1972, and 1973 for one study and in 1972 and 1973 for another study. Visual estimates of green sagewort control were made in 1971, 1972, 1973, and 1974. Repeat applications of 2,4-D ester at 2.24 or $3.36 \mathrm{~kg} / \mathrm{ha}$ effectively controlled green sagewort whether applied in 2 or 3 consecutive years. Dicamba or picloram, each in combination with 2,4-D ester, also effectively reduced the stand of green sagewort. Green sagewort was not controlled effectively by 2,4-D ester alone at rates less than $2.24 \mathrm{~kg} / \mathrm{ha}$ or $2,4,5-\mathrm{T}$ at rates of 1.12 or $2.24 \mathrm{~kg} / \mathrm{ha}$. Picloram, when applied alone, was not as effective as in combination with 2,4-D ester. Retreatment is necessary when attempting to control green sagewort. Two consecutive annual application of 2,4-D ester effectively reduced the stand. After reducing the stand of green sagewort, spraying every 2nd or 3rd year as a maintenance program may be adequate to keep populations of green sagewort plants at a minimum.

Productivity of grazing lands is often limited by unpalatable, nonnutritious, or poisonous plant growth (Arnold and Santelmann, 1966; Morrison, 1972). Green sagewort is a short-lived perennial that is native to the Great Plains. It does not produce vegetatively but is a prolific seed producer and will occur in dense stands when it becomes established.

Weed infestations on grazing lands are usually the result of mismanagement (Dalrymple et al., 1964; Klingman, 1953; Klingman, 1956). Green sagewort spreads rapidly under heavy grazing. A dense stand not only decreases forage production, but also alters livestock grazing patterns. Improved methods of weed control can be used in combination with improved grazing management. The most efficient way to control weeds is to prevent their occurrence, because when weeds are established, it is difficult to return these lands to a more productive state by management alone. If uscd properly, herbicides can be an effective tool in the total management program.

Retreatment is necessary to control certain weeds, particularly perennials. Selleck (1959) found that a single application of 2,4-D ester at $1.68 \mathrm{~kg} / \mathrm{ha}$ did not effectively control Artemisia absinthium L., but nearly complete control was

Authors are research agronomists, Agricultural Research Service, U.S. Department of Agriculture, Department of Agronomy, University of Nebraska, Lincoln 68503.

Morrow's present address is Northern Great Plains Research Center, P.O. Box 459, Mandan, North Dakota 58554 .

The study is a contribution of the Agr. Res. Serv., U.S. Dep. Agr. in cooperation with the Nebraska Agricultural Experiment Station. (Paper No. 3967.)

Manuscript received July 5, 1975. obtained when the same treatment was applied in the 2nd year. In Nebraska, McCarty and Scifres (1972) found that western ragweed (Ambrosia psilostachya DC.), was effectively controlled by two annual applicatons of 2,4-D, picloram or dicamba, but not by a single treatment. Bovey (1964) reported that 2,4-D,2,4,5-T, or silvex gave excellent topkill of sand sagebrush (Artemisia filifolia Torr.), but regrowth occurred the year after herbicide application.

This study was conducted to determine the response of green sagewort to repeated applications of several common herbicides.

\section{Methods and Materials}

In 1971, experimental plots were established in the Nebraska Sandhills to study green sagewort control. Plots 6.1 by $10.7 \mathrm{~m}$ were arranged in a randomized complete block design with four replications. The soil is a Valentine fine sand. The area receives an average of $50 \mathrm{~cm}$ of precipitation annually.

Plant species in the study area, in addition to green sagewort, include little bluestem (Andropogon scoparius Michx.), prairie sandreed [Calamovilfa longifolia (Hook.) Scribn.], blue grama [Bouteloua gracilis (H.B.K.) Lag. ex Steud.], prairie Junegrass [Koeleria cristata (L.) Pcrs.], ncedleandthread (Stipa comata Trin. and Rupr.), sixweeks fescue (Festuca octoflora Walt.), annual bromes (Bromus spp.). and western ragweed (Ambrosia psilostachya DC.). Green sagewort was present in moderate to dense stands and comprised approximately $80 \%$ of the weedy vegetation.

Herbicide treatments included the alkanolamine salt of 2,4-D [(2,4-dichlorophenoxy)acetic acid] and the propylene glycol butyl ether ester of 2,4-D, at 1.12, 2.24, and 3.36 $\mathrm{kg} / \mathrm{ha} ; 2,4,5-\mathrm{T}[(2,4,5$-trichlorophenoxy)acetic acid $]$ as the propylene glycol butyl ether ester at $2.24 \mathrm{~kg} / \mathrm{ha}$; the dimethylamine salt of dicamba (3,6-dichloro-o-anisic acid) at 0.28 and $0.56 \mathrm{~kg} / \mathrm{ha}$ in combination with 1.12 and $2.24 \mathrm{~kg} / \mathrm{ha} 2,4-\mathrm{D}$ ester, respectively; and picloram (4-amino-3,5,6-trichloropicolinic acid) as the potassium salt at 0.14 and $0.28 \mathrm{~kg} / \mathrm{ha}$ in combination with 1.12 and $2.24 \mathrm{~kg} / \mathrm{ha}$ 2,4-D ester, respectively. All treatments were applied with a tractor-mounted sprayer in 187 liters/ha solution with $0.3 \%$ of the surfactant X-77. ${ }^{1}$

Herbicide treatments were applied in 1971, 1972, and 1973 during late May or early June. The green sagewort plants were 5 to $10 \mathrm{~cm}$ tall at the time of herbicide application. Percentage of green sagewort control was visually estimated during the spring and fall of each year.

In 1972, another experiment was initiated to determine green sagewort control response to repeated herbicide treatments. Treatments and application methods were the same as

\footnotetext{
${ }^{1}$ Mention of a trade name, proprietary product, or specific equipment does not constitute a guarantee or warranty by the U.S. Dep. Agr. and does not imply its approval to the inclusion of other products that may be suitable.
} 
Table 1. Visual estimates of percentage of green sagewort control from herbicide treatments applied in 1971, 1972, and 1973. ${ }^{1}$

\begin{tabular}{lccccc}
\hline & \multirow{2}{*}{$\begin{array}{c}\text { Rate } \\
\text { Herbicide }\end{array}$} & \multicolumn{5}{c}{ Control (\%) } \\
\cline { 4 - 6 } \cline { 4 - 6 } Check & 0 & $0 / 30 / 71$ & $8 / 1 / 72$ & $8 / 21 / 73$ & $7 / 11 / 74$ \\
2,4-D ester & 1.12 & $50 \mathrm{~b}$ & $63 \mathrm{~b}$ & $0 \mathrm{c}$ & $0 \mathrm{~d}$ \\
2,4-D ester & 2.24 & $84 \mathrm{ab}$ & $89 \mathrm{a}$ & $90 \mathrm{a}$ & $91 \mathrm{~b}$ \\
2,4-D ester & 3.36 & $83 \mathrm{ab}$ & $93 \mathrm{a}$ & $95 \mathrm{a}$ & $95 \mathrm{ab}$ \\
2,4,5-T & 2.24 & $74 \mathrm{ab}$ & $76 \mathrm{a}$ & $58 \mathrm{~b}$ & $68 \mathrm{c}$ \\
Dicamba + & 0.28 & & & & \\
$\quad$ 2,4-D ester & 1.12 & $76 \mathrm{ab}$ & $90 \mathrm{a}$ & $100 \mathrm{a}$ & $96 \mathrm{ab}$ \\
Dicamba + & 0.56 & & & & \\
$\quad$ 2,4-D ester & 2.24 & $89 \mathrm{a}$ & $89 \mathrm{a}$ & $93 \mathrm{a}$ & $91 \mathrm{ab}$ \\
$\begin{array}{c}\text { Picloram }+ \\
\text { 2,4-D ester }\end{array}$ & 0.14 & & & & \\
$\begin{array}{c}\text { Picloram }+ \\
\text { 2,4-D ester }\end{array}$ & 1.12 & $78 \mathrm{ab}$ & $93 \mathrm{a}$ & $93 \mathrm{a}$ & $98 \mathrm{a}$ \\
\hline
\end{tabular}

${ }^{1}$ Means in the same column followed by the same letter do not differ significantly at the $5 \%$ level, by Duncan's multiple range test.

previously described, except that 2,4,5-T at $1.12 \mathrm{~kg} / \mathrm{ha}$ and picloram at $0.28 \mathrm{~kg} / \mathrm{ha}$ were added. These treatments were applied in either study in 1974 .

\section{Results and Discussion}

All herbicide treatments applied in 1971 resulted in some topgrowth control of green sagewort at the end of a single growing season (Table 1). Dicamba at $0.56 \mathrm{~kg} / \mathrm{ha}$ or picloram at $0.28 \mathrm{~kg} / \mathrm{ha}$, each in combination with $2.24 \mathrm{~kg} / \mathrm{ha}$ of $2,4-\mathrm{D}$ ester, resulted in a topkill of 89 and $98 \%$, respectively. The $1.12 \mathrm{~kg} / \mathrm{ha}$ rate of 2,4-D ester applied alone resulted in about $50 \%$ control by the end of the first growing season. The other treatments ranged in effectiveness from 74 to $84 \%$ topkill of green sagewort.

Herbicide treatments were reapplied in 1972. In August 1972, all herbicide applications applied for 2 consecutive years effectively reduced the stand of green sagewort. All treatments, with the exceptions of 2,4-D at $1.12 \mathrm{~kg} / \mathrm{ha}$ and $2,4,5-\mathrm{T}$ at $2.24 \mathrm{~kg} / \mathrm{ha}$, reduced the green sagewort population by about $90 \%$.

In 1973, herbicides were again applied. Evaluations from 1973 indicated that $2,4-\mathrm{D}$ ester at the rate of $1.12 \mathrm{~kg} / \mathrm{ha}$ or $2,4,5-\mathrm{T}$ at $2.24 \mathrm{~kg} / \mathrm{ha}$ reduced the stand of green sagewort by about 55\%. All other treatments resulted in more than $90 \%$ stand reduction of green sagewort. After three annual applic-

Table 2. Visual estimates of percentage of green sagewort control from herbicide treatments applied in 1972 and $1973 .^{1}$

\begin{tabular}{lcccc}
\hline & Rate & \multicolumn{3}{c}{ Control (\%) } \\
\cline { 4 - 5 } Herbicide & $(\mathrm{kg} / \mathrm{ha})$ & $8 / 1 / 72$ & $7 / 21 / 73$ & $7 / 11 / 74$ \\
\hline Check & 0 & $0 \mathrm{~d}$ & $0 \mathrm{c}$ & $0 \mathrm{c}$ \\
2,4-D ester & 1.12 & $40 \mathrm{bc}$ & $83 \mathrm{ab}$ & $89 \mathrm{ab}$ \\
2,4-D ester & 2.24 & $68 \mathrm{a}$ & $85 \mathrm{ab}$ & $98 \mathrm{a}$ \\
2,4-D ester & 3.36 & $69 \mathrm{a}$ & $93 \mathrm{a}$ & $100 \mathrm{a}$ \\
2,4,5-T & 1.12 & $34 \mathrm{bc}$ & $58 \mathrm{~b}$ & $72 \mathrm{~b}$ \\
2,4,5-T & 2.24 & $59 \mathrm{ab}$ & $80 \mathrm{ab}$ & $70 \mathrm{~b}$ \\
Dicamba + & 0.28 & & & \\
$\quad$ 2,4-D ester & 1.12 & & & \\
Dicamba + & 0.56 & & & \\
$\quad$ 2,4-D ester & 2.24 & $68 \mathrm{a}$ & $100 \mathrm{a}$ & $99 \mathrm{a}$ \\
Picloram + & 0.14 & & & \\
$\quad$ 2,4-D ester & 1.12 & $58 \mathrm{ab}$ & $93 \mathrm{a}$ & $98 \mathrm{a}$ \\
Picloram + & 0.28 & & & \\
$\quad$ 2,4-D ester & 2.24 & $79 \mathrm{a}$ & $100 \mathrm{a}$ & $100 \mathrm{a}$ \\
Picloram & 0.28 & $19 \mathrm{c}$ & $78 \mathrm{ab}$ & $82 \mathrm{ab}$ \\
\hline
\end{tabular}

${ }^{1}$ Means in the same column followed by the same letter do not differ significantly at the $5 \%$ level, by Duncan's multiple range test. ations of herbicides, all treatments except $1.12 \mathrm{~kg} / \mathrm{ha}$ of $2,4-\mathrm{C}$ ester and $2.24 \mathrm{~kg} / \mathrm{ha}$ of 2,4,5-T were equally effective for the control of green sagewort. In 1974, all treatments except 1.12 $\mathrm{kg} / \mathrm{ha}$ of $2,4-\mathrm{D}$ ester or $2.24 \mathrm{~kg} / \mathrm{ha} 2,4,5$ - $\mathrm{T}$ resulted in more than $90 \%$ stand reduction of green sagewort. No treatment was applied in 1974.

In 1972, the same treatments, with the additions of 2,4,5-T at $1.12 \mathrm{~kg} / \mathrm{ha}$ and picloram at $0.28 \mathrm{~kg} / \mathrm{ha}$, were applied in another study (Table 2). In August 1972, all treatments resulted in some degree of topkill compared with the untreated check.

Picloram at $0.28 \mathrm{~kg} / \mathrm{ha}$ in combination with $2.24 \mathrm{~kg} / \mathrm{ha}$ of 2,4-D ester resulted in 79\% topkill of green sagewort. The $2,4-\mathrm{D}$ ester at 2.24 or $3.36 \mathrm{~kg} / \mathrm{ha}$ and dicamba at $0.56 \mathrm{~kg} / \mathrm{ha}$ in combination with $2.24 \mathrm{~kg} / \mathrm{ha}$ of 2,4-D ester resulted in about $68 \%$ topkill.

Treatments were reapplied in 1973. All treatments reduced the stand of green sagewort. Dicamba at $0.56 \mathrm{~kg} / \mathrm{ha}$ or picloram at $0.28 \mathrm{~kg} / \mathrm{ha}$, each in combination with $2.24 \mathrm{~kg} / \mathrm{ha}$ of 2,4-D ester resulted in complete stand reduction of green sagewort when applied in 2 consecutive years. Dicamba at 0.28 $\mathrm{kg} / \mathrm{ha}$ in combination with $2,4-\mathrm{D}$ at $1.12 \mathrm{~kg} / \mathrm{ha}$ resulted in $95 \%$ control, and picloram at $0.14 \mathrm{~kg} / \mathrm{ha}$ in combination with 1.12 $\mathrm{kg} / \mathrm{ha} 2,4-\mathrm{D}$ ester and 2,4-D ester alone at $3.36 \mathrm{~kg} / \mathrm{ha}$ reduced the stand of green sagewort by about $93 \%$. The 1.12 or 2.24 $\mathrm{kg} / \mathrm{ha}$ rates of 2,4-D ester resulted in about $85 \%$ control of green sagewort compared with the untreated check. Green sagewort stand reduction was $58 \%$ when $1.12 \mathrm{~kg} / \mathrm{ha}$ of $2,4,5-\mathrm{T}$ was applied.

Picloram at 0.14 or $0.28 \mathrm{~kg} / \mathrm{ha}$ in combination with 1.12 or $2.24 \mathrm{~kg} / \mathrm{ha}$ of $2,4-\mathrm{D}$ ester, respectively, dicamba at 0.28 or $0.56 \mathrm{~kg} / \mathrm{ha}$ in combination with 1.12 or $2.24 \mathrm{~kg} / \mathrm{ha}$ of $2,4-\mathrm{D}$ ester, respectively, and 2,4-D ester alone at $3.36 \mathrm{~kg} / \mathrm{ha}$ were very effective in controlling green sagewort when treatments were applied in more than 1 year. In 1974, even though no treatments were applied, all treatments from previous years reduced the stand of green sagewort. All treatments except $1.12 \mathrm{~kg} / \mathrm{ha}$ of $2,4-\mathrm{D}$ ester, 1.12 or $2.24 \mathrm{~kg} / \mathrm{ha}$ of $2,4,5-\mathrm{T}$ or $0.28 \mathrm{~kg} / \mathrm{ha}$ of picloram achieved more than $90 \%$ stand reduction.

Green sagewort can be controlled effectively with herbicides if applied in more than 1 year. Application of herbicides in consecutive years is an effective measure for green sagewort control in grazing lands. After stands of green sagewort are reduced, it may be possible for the application of herbicides in alternate years to be effective in keeping weed populations at a minimum.

\section{Literature Cited}

Arnold, W. R., and P. W. Santelmann. 1966. The response of native grass and forbs to picloram. Weeds 14:74-76.

Bovey, R. W. 1964. Aerial application of herbicides for control of sand sagebrush. J. Range Manage. 17:25 3-256.

Dalrymple, R. L., D. D. Dwyer, and P. W. Santelmann. 1964. Vegetational responses following winged elm and oak control in Oklahoma. J. Range Manage. 17:249-253.

Klingman, D. L. 1953. A comparison of pasture weed control methods under three levels of management. Down to Earth 9(1):4-7.

Klingman, D. L. 1956. Weed control in pastures in the North Central Region. Weeds 4:369-375.

McCarty, M. K., and C. J. Scifres. 1972. Herbicidal control of western ragweed in Nebraska pastures. J. Range Manage. 25:290-292.

Morrison, J. 1972. Botanical deterioration of some sown grasslands in S.E. England. J. Brit. Grassland s Soc. 27:202.

Selleck, G. W. 1959. Chemical and cultural control of absinth. Proc. N. Cent. Weed Cont. Conf. 16:34-35. 